\title{
O VALOR NORMATIVO DOS TRATADOS INTERNACIONAIS DE DIREITOS HUMANOS E A EMENDA CONSTITUCIONAL 45/2004
}

\author{
THE NORMATIVE VALUE OF HUMAN RIGHTS TREATIES AND \\ CONSTITUTIONAL AMENDMENT 45/2004
}

\section{Elisa Resende Bueno da Fonseca*}

\begin{abstract}
SUMÁRIO: 1 Introdução. 2 O Estado brasileiro em face do sistema internacional de proteção dos direitos humanos. 3 Relações entre o Direito internacional e o Direito interno. 3.1 A hierarquia dos tratados internacionais de direitos humanos. $3.2 \mathrm{O}$ valor normativo dos tratados internacionais de direitos humanos ratificados pelo Brasil anteriormente à Emenda Constitucional n ${ }^{\circ} 45$. Conclusão. Referências.
\end{abstract}

RESUMO: A proposta desse estudo é analisar o modo pelo qual o Direito brasileiro incorpora os instrumentos internacionais de proteção dos direitos humanos, especificamente, a hierarquia normativa desses tratados internacionais no âmbito do Direito Interno. Nesse sentido, buscar-se-á analisar o artigo $5^{\circ}$, parágrafo $2^{\circ}$, da Constituição da República de 1988 , o qual diz que os direitos e garantias expressos na Constituição, "não excluem outros decorrentes do regime e dos princípios por ela adotados, ou dos tratados internacionais em que a República Federativa do Brasil seja parte"; bem como será explorada a alteração introduzida pela Emenda Constitucional 45 , de 08 de dezembro de 2004 , que acrescentou o parágrafo $3^{\circ}$, ao artigo $5^{\circ}$, dispondo que os tratados e convenções internacionais de proteção dos direitos humanos que forem aprovados "em cada Casa do Congresso Nacional, em dois turnos, por três quintos dos votos dos respectivos membros, serão equivalentes às emendas à Constituição". A posição adotada por este trabalho é a de que, por força do artigo $5^{\circ}$, parágrafo $2^{\circ}$, da Carta de 1988 , todos os tratados de direitos humanos, independentemente do quorum de sua aprovação, são materialmente constitucionais, compondo o bloco de constitucionalidade. E mais, é sensato crer que, ao inserir o parágrafo $3^{\circ}$, sem nenhuma ressalva abjuratória dos tratados sobre direitos humanos concluídos mediante procedimento diverso, o constituinte os elevou à categoria dos tratados de nível constitucional. Dessa forma, deve-se atribuir hierarquia normativa constitucional tanto aos tratados internacionais de direitos humanos ratificados após a Emenda Constitucional $n^{\circ} 45$, quanto àqueles ratificados antes da referida Emenda.

Palavras-chave: direitos. humanos. tratados.

ABSTRACT: The purpose of this study is to analyse the way the brazilian Law incorporate its international instruments of protection from the human rights. This way, the article $5^{\text {th }}, 2^{\text {nd }}$ of the Constitution of the Republic of 1988, which allowed expressive rights, somehow wouldn't exclude none from anybody of the regime taken, and from the principle followed, or from the international treat, which Brazil be a member. As well as the alteration introduced by the $45^{\text {th }}$ Constitutional Emends, from December $08^{\text {th }}$ of 2004 , which added on the $3^{\text {rd }}$ paragraph, in the $5^{\text {th }}$

* Advogada e aluna da Disciplina Isolada de Mestrado Teoria do Estado e Globalização na Pontifícia Universidade Católica de Minas Gerais, com endereço profissional na Av. Antônio Gabriel de Resende, $n^{\circ}$ 529, Bairro Tereza Cristina, São Joaquim de Bicas / MG e endereço eletrônico: elisaresendebueno@yahoo.com.br. 
article, disposing that the International conventions and the treats of human rights that would be approved, in each House of the National Congress, in two turns, for three fifth $(3 / 5)$ votes of the respective members, would be likely the emends of the Constitution. The taken position for this job understands that, the strength of the $5^{\text {th }}$ article, $2^{\text {nd }}$, of the letter of 1988 , all the treat of the human treats, independently of its approving quorum for it, the rights are constitutionally materially, compound the constitution. It's smarter believe, that promulgating the $3^{\text {rd }}$ paragraph, witout resaving abjuratory of the treats about human rights done by simple procces, the constituters leveled up to the constitutional category of treats. Therefore, even the international treats of human rights ratified after the 45 Constitutional Emend, or those ratified before the referred Emend, will have the hierarchy of the normative constituition.

Keywords: human. rights. treaties.

\section{INTRODUÇÃO}

A proposta desse estudo é analisar o modo pelo qual o Direito brasileiro incorpora os instrumentos internacionais de proteção dos direitos humanos. Especificamente, a hierarquia normativa desses tratados internacionais no âmbito do Direito Interno.

A análise da referida problemática argüida tem como escopo definir o grau hierárquico que ocupam os tratados internacionais de direitos humanos, bem como, se é possível, dentre os tratados de direitos humanos, atribuir-lhes valores normativos diferenciados exclusivamente em virtude do seu quorum de aprovação. Definições estas que, uma vez concluídas, proporcionariam aos indivíduos, beneficiários diretos dessas normas, maior segurança e garantia quando da aplicabilidade dos seus direitos. Lado outro, permitiriam aos hermeneutas, ampla certeza quando da correta interpretação sistemática das leis ${ }^{1}$.

Nesse sentido, buscar-se-á analisar o modo pelo qual a Constituição brasileira incorpora os tratados internacionais de proteção dos direitos humanos, definindo o status hierárquico atribuído a eles, vez que, é de grande importância à efetiva incorporação destes tratados no plano nacional para que os seus propósitos sejam alcançados ${ }^{2}$.

Em suma, objetiva-se com este artigo demonstrar a integração das sistemáticas nacional e internacional que dispõem sobre direitos da pessoa humana, em prol do modelo que mais eficazmente possa proteger

1 Salienta-se que a instabilidade não pode vigorar no âmbito das ciências jurídicas. Quanto mais no que tange aos direitos humanos. Vez que este engloba uma série de outros direitos.

2 É nesse cenário que será investigado a dinâmica da relação entre a Constituição Federal de 1988 e os tratados internacionais de proteção dos direitos do homem. Afinal, entende-se que a Carta de 1988 situa-se como marco jurídico da transição democrática e da institucionalização dos direitos humanos no Brasil. 
tais direitos ${ }^{3}$.

Por fim, esclarece-se o modo pelo qual se organiza este trabalho. A começar pelo enfoque analítico adotado, importa destacar que, optouse pelo estudo sistemático das normas, ordenando-as segundo princípios e, tendo em vista a sua efetiva aplicação. Vale dizer, a monografia proposta será desenvolvida através de pesquisas documentais e estruturada de acordo com a dogmática jurídica ${ }^{4}$.

\section{O ESTADO BRASILEIRO EM FACE DO SISTEMA INTERNACIONAL DE PROTEÇÃO DOS DIREITOS HUMANOS}

Ao estudar a posição do Brasil em relação ao sistema internacional de proteção dos Direitos Humanos, Piovesan (2008a, p.21) elege como importante ponto de partida, a análise do processo de democratização no Brasil, o qual fora deflagrado em 1985, quando, então, o Estado brasileiro começou a ratificar relevantes tratados internacionais de Direitos Humanos.

Como é sabido, durante o longo período de 1964 a 1985, perdurou no Brasil o regime militar ditatorial ${ }^{5}$. Finda essa fase autoritária, o país se viu em transição para um governo democrático. Tal fase transitória, segundo Piovesan (2008a, p.23), exigiu a elaboração de um novo código, que refizesse o pacto político-social. Tal processo culminou na promulgação de uma nova ordem constitucional - a Constituição de outubro de 1988.

Rompendo com a ordem jurídica marcada pelo autoritarismo, a Constituição brasileira de 1988, com o propósito de instaurar a

3 Vale dizer, este trabalho se concentra no modo como as ordens nacional e internacional se conjugam para reafirmar o valor dos direitos humanos.

4 Neste trabalho, a dogmática será realizada através de posições doutrinárias sobre o tema, bem como leis e jurisprudências dos tribunais, a fim de demonstrar que não há consenso na interpretação dos parágrafos $2^{\circ}$ e $3^{\circ}$, do artigo $5^{\circ}$, da Constituição da República, que dispõem sobre o valor normativo dos tratados internacionais sobre Direitos Humanos. Daí dizer que, este projeto adota como metodologia básica a Dogmática Jurídica Internacional e Constitucional.

$5 \mathrm{O}$ qual significou a mais forte repressão de toda a experiência brasileira, estabelecendo uma verdadeira hierarquia do Poder Executivo sobre os Poderes Legislativo e Judiciário, bem como sobre os estados federados, de forma a revogar direitos constitucionais, censurar meios de comunicação, e outras tantas atrocidades que desestruturaram todo o país. 
democracia no país, bem como de institucionalizar os direitos humanos, faz como que uma verdadeira revolução na ordem jurídica brasileira, passando a ser "o marco fundamental da abertura do Estado brasileiro ao regime democrático e à normatividade internacional de proteção dos direitos humanos", conforme comenta Mazzuoli (2000a).

Ainda em conformidade com o entendimento de Mazzuoli, podese dizer que, como marco fundamental do processo de institucionalização dos direitos humanos no Brasil, a Carta de 1988, no artigo $1^{\circ}$, inciso III, ergueu a "dignidade da pessoa humana" a princípio fundamental. De forma a instituir, com este princípio, "um novo valor que confere suporte axiológico a todo o sistema jurídico e que deve ser sempre levado em conta quando se trata de interpretar qualquer das normas constantes do ordenamento jurídico nacional", de acordo com o que escreve Mazzuoli (2000a).

Kant já explicava sobre o princípio da dignidade da pessoa humana. O referido filósofo dizia que as pessoas devem existir como um fim em si mesmo e jamais como um meio, que podia ser arbitrariamente utilizado para algum objetivo. Segundo Kant, as pessoas são dotadas de dignidade, na medida em que têm um valor intrínseco. Desse modo, deve-se tratar a humanidade, na pessoa de cada ser, sempre como um fim em si mesmo, nunca como um meio, conforme comenta Piovesan (2008) ao citar Kant.

Importa destacar o entendimento sintetizado de Piovesan, sobre o nascimento da Constituição de 1988:

A Carta de 1988 institucionaliza a instauração de um regime político democrático no Brasil. Introduz também indiscutível avanço na consolidação legislativa das garantias e direitos fundamentais e na proteção de setores vulneráveis da sociedade brasileira. A partir dela, os direitos humanos ganham relevo extraordinário, situando-se a Carta de 1988 como o documento mais abrangente e pormenorizado sobre os direitos humanos jamais adotado no Brasil. [...] Considerando que toda Constituição há de ser compreendida como unidade e como sistema que privilegia determinados valores sociais, pode-se afirmar que a Carta de 1988 elege o valor da dignidade humana como valor essencial que lhe dá unidade de sentido. Isto é, o valor da dignidade humana informa a ordem constitucional de 1988, imprimindo-lhe uma feição particular. (PIOVESAN, 2008a, p.24-28). 
Daí entender que, tanto o Direito Internacional dos Direitos Humanos, quanto a Constituição brasileira, foram concretizados com ênfase ao princípio da dignidade da pessoa humana. Sustenta-se assim, "a dignidade da pessoa humana como verdadeiro superprincípio, a orientar tanto o Direito Internacional como o Direito interno", conforme comenta Piovesan (2008a, p.30).

Por fim, importa destacar que, além das inovações constitucionais constituírem fator fundamental para a ratificação de importantes tratados internacionais de proteção dos direitos humanos, contribuíram também para a reorganização da agenda internacional do Estado brasileiro. Esta reorganização se deu, de acordo com Piovesan (2008b, p.7), com o objetivo de compor uma imagem mais positiva do Estado brasileiro no contexto internacional, passando à um modo mais condizente com as transformações internas decorrentes do processo de democratização, para então, figurar como país respeitador e garantidor dos direitos humanos.

Logo, faz-se clara a relação entre o processo de democratização no Brasil e a ratificação de importantes instrumentos internacionais de proteção dos direitos humanos, tendo em vista que, ao mesmo tempo que a democratização contribuiu para a incorporação de relevantes tratados internacionais de direitos humanos, a ratificação permitiu o fortalecimento do processo democrático, vez que ampliou os direitos por ele assegurado, de acordo com o que escreve Piovesan (2008b, p.7).

\section{RELAÇÕES ENTRE O DIREITO INTERNACIONAL E O DIREITO INTERNO}

Antes de discutir o tópico seguinte, importa apresentar um breve estudo sobre a hipótese de conflitar norma internacional e norma interna. Para tanto, indispensável se torna o estudo das teorias doutrinárias monista e dualista, as quais dizem respeito à possibilidade e viabilidade da convivência da soberania dos Estados membros com a sua condição de sujeitos de Direito Internacional.

O primeiro estudo sistemático da matéria, feito por Heinrich Triepel, em 1899, conforme consta da obra de Mello (2002, p.113), deu origem ao dualismo. Para este jurista, o Direito Internacional e o Direito Interno são duas ordens jurídicas distintas processadas paralelamente. Dentro dessa teoria há dois posicionamentos diferentes:

$\mathrm{O}$ primeiro entende que, quando do conflito de normas interna e internacional, a primazia é da norma de Direito interno. Assim, para que 
uma norma internacional tenha vigência no âmbito interno de determinado Estado, é necessária a sua transformação em norma de Direito interno, de forma a compor o sistema jurídico interno. Assim, só se aplica a norma do Direito Internacional se se integrar ao universo de normas jurídicas internas de determinado Estado, segundo Ribeiro (2001, p.53).

Lado outro, mas ainda analisando o dualismo, há uma outra corrente que entende pela primazia da norma de Direito Internacional, de forma que só aplicará a norma interna se esta corresponder à norma internacional. Vale dizer, a norma de Direito Interno só terá vigência se não contrariar norma de Direito Internacional, de acordo com o que escreve Ribeiro (2001, p.54).

Confrontando com a corrente dualista, a concepção monista defende a unidade dos sistemas jurídicos, ou seja, sustenta a existência de um só sistema universal. Para essa teoria, tanto o Direito Internacional como o Direito Interno constituem um único sistema jurídico, sendo que, em caso de conflito de normas, pode predominar o Direito Internacional ou o Direito Interno, dependendo da posição adotada pelo Estado, conforme explica Ribeiro (2001, p.38-40).

De acordo com o que escreve Mazzuoli (2000a) no que tange aos tratados internacionais de proteção dos direitos humanos, destaca-se que, foi adotada no Brasil a concepção monista, segundo a qual, a partir da ratificação o tratado produz efeitos jurídicos tanto no plano internacional como no plano interno. Vale dizer, de acordo com o $\S 1^{\circ}$, do artigo $5^{\circ}$ da Carta de 1988, "as normas definidoras de direitos e garantias fundamentais tem aplicação imediata".

Nesta ordem de idéias, o Direito Internacional e o Direito Interno compõem uma única ordem jurídica, tendo em vista que a incorporação dos tratados de direitos humanos na ordem interna brasileira se faz de imediato, a partir do ato da ratificação.

Importa destacar o comentário de Mazzuoli:

Essa tendência em se admitir a primazia do Direito Internacional sobre o Direito Interno é mundial, tendo ganhado foros de regra jurídica convencional, com $o$ advento da Convenção de Viena sobre o Direito dos Tratados, de 1969, que a previu expressamente no seu art. 27, nesses termos: "Direito Interno e Observância de Tratados. Uma parte não pode invocar as disposições de seu direito interno para justificar o inadimplemento de um 
tratado". [...] Trata-se de verdadeiro princípio básico de Direito Internacional essa primazia. Aliás, admitir a unidade de ambos os ordenamentos jurídicos (interno e internacional), bem como a incorporação do Direito Internacional dos Direitos Humanos no Direito Interno, sem a necessidade de que este absorva o primeiro através de uma fonte legislativa, significa compatibilizar harmonicamente a Constituição com o Direito Internacional, o que tem a grande vantagem de evitar os possíveis conflitos existentes (MAZZUOLI, 2000a).

$\mathrm{Na}$ mesma linha, Celso Ribeiro Bastos (1989, p. 396), em comentário ao $\S 2^{\circ}$ do artigo $5^{\circ}$ da Magna Carta, o qual dispõe que os direitos e garantias expressos na Constituição "não excluem outros decorrentes do regime e dos princípios por ela adotados, ou dos tratados internacionais em que a República Federativa do Brasil seja parte". Escreve que, ante o referido dispositivo legal, não será mais possível a aplicação da teoria dualista, ou seja, será possível a invocação de tratados em que o Brasil seja parte, sem a necessidade de edição pelo Poder Legislativo de ato com força de lei de modo a outorgar às suas disposições vigência ou obrigatoriedade no plano do ordenamento jurídico interno.

Por fim, merece citar Jacob Dolinger, ora citado por Piovesan (2008):

Hans Kelsen, que deu ao monismo jurídico sua expressão científica definitiva, advogava a primazia do direito internacional sobre o direito interno por motivos de ordem prática: a primazia do direito interno acarretaria o despedaçamento do direito e, consequentemente, sua negação. De acordo com a teoria kelsiana, a ordem jurídica interna deriva da ordem jurídica internacional como sua delegada. Esta foi a posição abraçada pelos internacionalistas brasileiros. (DOLINGER apud PIOVESAN. 2008a, p.61).

Assim, não há como deixar de reconhecer a unidade do sistema jurídico e a superioridade do Direito Internacional, mesmo sabendo que, conforme comentário de Fernando Jayme (2005, p.58) "não há teorias, monista ou dualista, aplicadas de forma absoluta".

\subsection{A Hierarquia dos Tratados Internacionais de Direitos Humanos}


A Constituição de 1988 , em seu artigo $5^{\circ}, \S 2^{\circ}$, dispõe que os direitos e garantias expressos na Constituição "não excluem outros decorrentes do regime e dos princípios por ela adotados, ou dos tratados internacionais em que a República Federativa do Brasil seja parte" ${ }^{6}$.

Antes de aprofundar na análise sobre o presente tema, Piovesan já se arisca a concluir que:

Ao prescrever que 'os direitos e garantias expressos na Constituição não excluem outros direitos decorrentes dos tratados internacionais', a contrario sensu, a Carta de 1988 está a incluir, no catálogo de direitos constitucionalmente protegidos, os direitos enunciados nos tratados internacionais em que o Brasil seja parte. Esse processo de inclusão implica a incorporação pelo Texto Constitucional de tais direitos. (2008a, p.52).

Segundo Piovesan (2008a, p.52), ao incorporar os direitos oriundos dos tratados internacionais de direitos humanos, a Constituição brasileira atribui aos direitos internacionais uma natureza diferenciada, qual seja, a de norma constitucional ${ }^{7}$.

Segundo André Gonçalves Pereira e Fausto de Quadros, à expressão "não excluem", constante do $\S 2 .^{\circ}$ do art. 5. ${ }^{\circ}$ da Carta Magna brasileira,

[...] não pode ser concedido um alcance meramente quantitativo: ela tem de ser interpretada como querendo significar também que, em caso de conflito entre as normas constitucionais e o Direito Internacional em matéria de direitos fundamentais, será este que prevalecerá. [...] Quanto aos demais tratados de Direito Internacional Convencional particular, aí sim, pensamos que eles cedem perante a Constituição, mas tem valor supralegal, isto é, prevalecem sobre a lei interna, anterior e posterior.

6 Importa destacar que, a Carta de 1967, no artigo 153, § 36, previa: “A especificação dos direitos e garantias expressos nessa Constituição não exclui outros direitos e garantias decorrentes do regime e dos princípios que ela adota". Logo, o novo diploma legal inclui entre os direitos constitucionalmente tutelados os direitos protegidos pelos tratados internacionais que o Brasil seja parte.

7 Isso se dá através da interpretação sistemática e teleológica do Texto Constitucional, principalmente diante da força ampliativa dos valores da dignidade da pessoa humana, bem como dos direitos fundamentais, como parâmetros axiológicos a orientar a compreensão do fenômeno constitucional. 
Importa ainda, perceber que, na inteligência do artigo $5^{\circ}, \S 2^{\circ}$ da Constituição de 1988, o status do produto normativo convencional, no que se refere à proteção dos direitos humanos, não pode ser outro que não o de verdadeira norma materialmente constitucional. Diz-se "materialmente constitucional", vez que os tratados não integram, formalmente, o Texto Constitucional. Se esse fosse o caso, demandaria um procedimento de emenda à Constituição, previsto no art. $60, \S 2 .^{\circ}$, o qual prevê que tal proposta "será discutida e votada em cada Casa do Congresso Nacional, em dois turnos, considerando-se aprovada se obtiver, em ambos, três quintos dos votos dos respectivos membros". Integram os tratados de proteção dos direitos humanos, entretanto, o conteúdo material ou núcleo material mínimo da Constituição, enfim, o seu "bloco de constitucionalidade", como escreve Canotilho (1993, p.982).

Conforme leciona Mazzuoli:

A Carta de 1988 , no $§ 2 .^{\circ}$ do seu art. $5 .^{\circ}$, não se refere à lei, mas tão-somente aos direitos por ela, Constituição, assegurados, ou inscritos nos tratados internacionais em que a República Federativa do Brasil seja parte. De modo que se uma lei contemplar outro direito ou garantia que não esteja previsto no corpo da Constituição, esta lei, sem ferir o texto constitucional, poderá ser revogada por outra que lhe seja posterior. Entretanto, se tal direito ou garantia vier expresso em tratado de direitos humanos ratificado pelo Estado brasileiro, a lei interna não poderá revogá-lo, diante do status de norma constitucional que detém tais instrumentos internacionais. (MAZZUOLI, 2000a).

Dessa forma, deve-se entender que, os direitos internacionais provenientes de tratados, em face do $\S 2^{\circ}$ do artigo $5^{\circ}$ da Carta de 1988, passam a compor o chamado "bloco de constitucionalidade", e não o texto constitucional propriamente dito.

Essa opção do constituinte de 1988 se justifica ante o caráter especial dos tratados de direitos humanos. Vale dizer, enquanto os tratados que dispõem de assuntos outros que não seja direitos humanos têm força hierárquica infraconstitucional - de acordo com o artigo 102, III, "b" da Constituição da República (o qual admite o cabimento de recurso extraordinário ao Supremo Tribunal Federal de decisão que 
declarar a inconstitucionalidade de tratado). Os tratados internacionais de proteção aos direitos humanos detêm natureza de norma constitucional. O referido caráter especial se dá, na medida em que estes buscam a salvaguarda dos direitos do ser humano, enquanto aqueles buscam somente o equilíbrio e a reciprocidade de relações entre Estados-partes, conforme comenta Piovesan (2008b, p.10).

O termo "inconstitucionalidade dos tratados", utilizado pelo constituinte no artigo 102, III, "b" da Constituição da República, significa que é perfeitamente válida a declaração de inconstitucionalidade dos instrumentos internacionais tradicionais ou comuns pelo Pretório Excelso, diferentemente dos tratados de direitos humanos, que, conforme leciona Mazzuoli (2000a) são considerados cláusulas pétreas. E, como é cediço, não se declara a inconstitucionalidade de clausulas pétreas, vez que dispõem sobre direitos e garantias fundamentais. Não podendo ser abolidos nem mesmo pela via de Emenda à Constituição.

Daí dizer que, os tratados internacionais que tratam de assuntos outros que não direitos humanos, têm hierarquia infraconstitucional, mas supralegal. Esse entendimento, segundo Piovesan (2008b, p.11), se coaduna com o princípio da boa-fé, vigente no direito internacional - o pacta sunt servanda -, bem como, com o artigo 27 da Convenção de Viena, o qual dispõe que não cabe ao Estado invocar disposições de seu direito interno como justificativa para o não cumprimento de norma internacional.

À primeira análise, a conclusão que se extrai é a de que os tratados internacionais comuns ocupam a mesma hierarquia das leis federais, sendo, portanto, aplicável, no caso de conflito, a regra lex posterior derogat priori. Foi inclusive com base no mencionado dispositivo constitucional que o STF passou a acolher a concepção que os tratados internacionais $\mathrm{e}$ as leis federais apresentavam a mesma hierarquia jurídica. Mas, segundo já fora assentado, os tratados internacionais comuns incorporados ao ordenamento brasileiro estão, na escala hierárquica das normas, numa posição intermediária, situando-se abaixo da Constituição, mas acima da legislação infraconstitucional, não podendo ser revogados por lei posterior.

Conforme comenta Piovesan (2008b, p.11), "essa concepção não apenas compromete o princípio da boa-fé, mas constitui afronta à Convenção de Viena sobre o Direito dos Tratados".

Mas, em 1977, a Corte Suprema adotou o entendimento que equipara juridicamente o tratado internacional à lei federal. Rezek, 
explica o entendimento do Supremo Tribunal Federal à época:

De setembro de 1975 a junho de 1977 estendeu-se, no plenário do Supremo Tribunal Federal, o julgamento do RE 80.004, em que ficou assentada, por maioria, a tese de que, ante a realidade do conflito entre tratado e lei posterior, esta, porque expressão última da vontade do legislador republicano deve ter sua prevalência garantida pela justiça - sem embargo das consequências do descumprimento do tratado, no plano internacional. Admitiram as vozes majoritárias que, faltante na Constituição do Brasil garantia de privilégio hierárquico do tratado internacional sobre as leis do Congresso, era inevitável que a justiça devesse garantir a autoridade da mais recente das normas, porque paritária sua estrutura no ordenamento jurídico. (REZEK, 2000, p.106).

Contudo, realça Mello (2001, p.70) que, quando do julgamento do recurso extraordinário n. 80.004, decidido em 1977, o Supremo Tribunal Federal violou a Convenção de Viena, que, em seu artigo 27, não admite o descumprimento de tratado por mudança de direito interno superveniente.

Tal dispositivo internacional reitera a importância do princípio da boa-fé, pelo qual cabe ao Estado cumprir com as normas internacionais, que livremente consentiu ${ }^{8}$. Além do mais, é cediço que o término de um tratado está submetido à denúncia, vale dizer, ato unilateral do Estado pelo qual manifesta sua vontade de deixar de ser parte de um tratado. Assim, inexistindo o ato da denúncia, persiste a obrigação do Estado parte no âmbito internacional.

Embora a decisão do Supremo Tribunal Federal, de atribuir status paritário de lei ordinária aos tratados internacionais ratificados pelo Brasil, tenha sido concluída antes da publicação da Constituição de 1988, verifica-se que a mesma posição fora reiterada, pela mesma Corte, em 1995, quando do julgamento de Habeas Corpus n. 72.131-RJ, relativo à prisão civil por dívida do depositário infiel.

Importa citar a fundamentação dada pelo Ministro Celso de Mello, quando do referido julgamento:

Inexiste, na perspectiva do modelo constitucional vigente

8 Ora, se o Estado, no uso de sua soberania, ratifica um tratado internacional, não pode, simplesmente, deixar de cumprir. 
no Brasil, qualquer procedência ou primazia hierárquiconormativa dos tratados ou convenções internacionais sobre o direito positivo interno, sobretudo em face das cláusulas inscritas no texto da Constituição da República, eis que a ordem normativa externa não se superpõe, em hipótese alguma, ao que prescreve a Lei Fundamental da República. [...] A circunstancia do Brasil haver aderido ao Pacto de São José da Costa Rica - cuja posição, no plano da hierarquia das fontes jurídicas, situa-se no mesmo nível de eficácia e autoridade das leis ordinárias internas - não impede que o Congresso Nacional, em tema de prisão por dívida, aprove legislação comum instituidora desse meio excepcional de coerção processual [...]. Os tratados internacionais não podem transgredir a normatividade emergente da Constituição, pois, além de não disporem de autoridade para restringir a eficácia jurídica das cláusulas constitucionais, não possuem força para conter ou para delimitar a esfera de abrangência normativa dos preceitos inscritos no texto da Lei Fundamental. [...] Parece-me irrecusável, no exame da questão concernente à primazia das normas de direito internacional público sobre a legislação interna ou doméstica do Estado brasileiro, que não cabe atribuir, por efeito do que prescreve o artigo $5^{\circ}$, parágrafo $2^{\circ}$, da Carta Política, um inexistente grau hierárquico das convenções internacionais sobre o direito positivo interno vigente no Brasil, especialmente sobre as prescrições fundadas em texto constitucional, sob pena de essa interpretação inviabilizar, com manifesta ofensa à supremacia da Constituição - que expressamente autoriza a instituição da prisão civil por dívidas em duas hipóteses extraordinárias (CF, artigo $5^{\circ}$, LXVII) - o próprio exercício, pelo Congresso Nacional, de sua típica atividade políticojurídica consistente no desempenho da função de legislar. [...] A indiscutível supremacia da ordem constitucional brasileira sobre os tratados internacionais, além de traduzir um imperativo que decorre de nossa própria Constituição (artigo 102, III, “b”), reflete o sistema que, com algumas poucas exceções, tem prevalecido no campo do direito comparado. (HC 72.131 de 1995).

Porém, o presente artigo, entende diferente. Defende, ao revés, que atribuir hierarquia constitucional aos tratados internacionais de proteção aos direitos humanos, com fundamento no princípio da prevalência da norma mais favorável, é perfeitamente possível na Carta de 1988, bem como com sua principiologia, e, em especial com o 
princípio da dignidade da pessoa humana, que, conforme salienta Piovesan, "é valor fundante do sistema constitucional" (PIOVESAN, 2008a, p.64).

Assim, continua-se a insistir que não se aplica a equiparação à lei ordinária aos tratados internacionais de direitos humanos, vez que, a Carta de 1988, garante, aos mesmos, privilégio hierárquico, reconhecendo-lhes natureza constitucional.

Daí, dizer que, o direito brasileiro opta por um "sistema misto disciplinador dos tratados", conforme escreve Piovesan (2008 a, p.67). Segundo ela, o referido sistema se caracteriza por combinar regimes jurídicos diferentes, vale dizer, aplica-se um regime aos tratados de direitos humanos, e outro, aos tratados comuns. De forma que, por força do artigo $5^{\circ}, \S 2^{\circ}$, da Constituição Federal, aos tratados internacionais que versam sobre direitos humanos é dada hierarquia constitucional, enquanto que, aos tratados internacionais tradicionais, atribui-se hierarquia infraconstitucional.

Pois bem, até agora foram apresentados duas concepções sobre a hierarquia normativa dos tratados de proteção aos direitos humanos, quais sejam, a Constitucional (posição defendida por este trabalho) e a concepção que confere à esses tratados hierarquia de lei ordinária. Restam ainda outras duas concepções doutrinárias: a que sustenta a supraconstitucionalidade dos tratados de direitos humanos e a que sustenta a hierarquia infraconstitucional, mas supralegal, desses mesmos tratados.

Segundo Pereira e Quadros os tratados de direitos humanos têm hierarquia constitucional. Os mesmos justificam o posicionamento adotado:

No Brasil, a Constituição de 1988 não regula a vigência do Direito Internacional na ordem interna, salvo quanto aos tratados internacionais sobre os direitos do homem. [...] Ao estabelecer que os direitos fundamentais consagrados na Constituição não excluem quaisquer outros constantes das regras aplicáveis do Direito Internacional, o dispositivo legal, ainda que implicitamente, está a conceder grau supraconstitucional a todo o Direito Internacional dos Direitos do Homem, tanto de fonte consuetudinária, como convencional. De facto, à expressão "não excluem" não pode ser concedido um alcance meramente quantitativo: ela tem de ser interpretada como querendo significar também que, em caso de conflito entre as normas constitucionais e o 
Direito Internacional em matéria de direitos fundamentais, será este que prevalecerá. (PEREIRA; QUADROS, 1993, p. 103 - 117).

Logo, aqueles que entendem pela supraconstitucionalidade dos tratados de proteção dos direitos humanos, crêem na verdadeira supremacia da ordem internacional sobre a ordem nacional. Mello é um grande defensor da preponderância dos tratados internacionais de direitos humanos em relação as normas constitucionais, que, não teriam, de acordo com o seu entender, poderes revogatórios em relação às normas internacionais ${ }^{9}$.

Augustín Gordillo entende da mesma forma:

A supremacia da ordem supranacional sobre a ordem nacional preexistente não pode ser senão uma supremacia jurídica, normativa, detentora de força coativa e de imperatividade. Estamos, em suma, ante um normativismo supranacional. Concluímos, pois, que as características da Constituição, como ordem jurídica suprema do direito interno, são aplicáveis em um todo às normas da Convenção, enquanto ordem jurídica suprema supranacional. (GORDILLO apud PIOVESAN. 2008a, p.68).

Nessa mesma direção, Accioly (1998, p.61-63), argumenta que o Direito Internacional é superior ao Estado, e, é por esse motivo que deriva de um princípio superior à vontade dos Estados. Segundo ele, não é verdade que o poder do Estado é uma delegação do Direito Internacional; mas, é indiscutível que este constitui um limite jurídico ao poder do Estado ${ }^{10}$.

Porém, há de ser considerada a dificuldade de adequação dessa tese à realidade dos Estados que, como é o caso do Brasil, "estão fundados em sistema regidos pelo princípio da supremacia formal e material da Constituição sobre todo o ordenamento jurídico", conforme crítica feita pelo Ministro Gilmar Mendes, quando do julgamento do RE

9 Em outros termos, nem mesmo emenda constitucional teria o condão de suprimir o dispositivo internacional subscrito pelo Estado em tema de direitos humanos, conforme fora citado pelo Ministro Gilmar Mendes, em seu voto quando do julgamento do RE 466.343 em dezembro de 2008.

10 Daí, entender que, no universo de leis internas, os tratados incorporados formam um direito irrevogável pela lei interna comum. De forma que, as disposições de uma lei interna não podem prevalecer sobre as do tratado. 
466.343 em dezembro do ano de 2008. E continua, "entendimento diverso anularia a própria possibilidade do controle da constitucionalidade desses diplomas internacionais".

Por fim, destaca-se ainda, a concepção que atribui hierarquia infraconstitucional, mas supralegal, dos tratados de direitos humanos. A qual foi adotada, recentemente, pelo Corte Suprema, quando do julgamento do supracitado RE 466.343, do dia 3 de dezembro de 2008. O qual prevaleceu no Supremo Tribunal Federal o voto do Ministro Gilmar Mendes (por cinco votos a quatro), ficando afastado o posicionamento do Ministro Celso de Mello, que reconhecia valor constitucional a tais tratados. Note-se que, o Supremo Tribunal Federal não mais adota a equiparação dos tratados de direitos humanos às leis ordinárias, que inclusive fora objeto de citação do presente trabalho, nos dizeres do Ministro Celso de Mello.

$\mathrm{O}$ atual posicionamento do Supremo se embasou no voto do Ministro Gilmar Mendes, o qual entende que:

Parece mais consistente a interpretação que atribui a característica de supralegalidade aos tratados e convenções de direitos humanos. Essa tese pugna pelo argumento de que os tratados sobre direitos humanos seriam infraconstitucionais, porém, diante de seu caráter especial em relação aos demais atos normativos internacionais, também seriam dotados de um atributo de supralegalidade. Em outros termos, os tratados sobre direitos humanos não poderiam afrontar a supremacia da Constituição, mas teriam lugar especial reservado no ordenamento jurídico. Equipará-los à legislação ordinária seria subestimar o seu valor especial no contexto do sistema de proteção dos direitos da pessoa humana. [...] Assim, a premente necessidade de se dar efetividade à proteção dos direitos humanos nos planos interno e internacional torna imperiosa uma mudança de posição quanto ao papel dos tratados internacionais sobre direitos na ordem jurídica nacional. É necessário assumir uma postura jurisdicional mais adequada às realidades emergentes em âmbitos supranacionais, voltadas primordialmente à proteção do ser humano. Como enfatiza Cançado Trindade, "a tendência constitucional contemporânea de dispensar um tratamento especial aos tratados de direitos humanos é, pois, sintomática de uma escala de valores na qual o ser humano passa a ocupar posição central". [...] Portanto, diante do inequívoco caráter especial dos tratados internacionais que 
cuidam da proteção dos direitos humanos, não é difícil entender que a sua internalização no ordenamento jurídico, por meio do procedimento de ratificação previsto na Constituição, tem o condão de paralisar a eficácia jurídica de toda e qualquer disciplina normativa infraconstitucional com ela conflitante. Nesse sentido, é possível concluir que, diante da supremacia da Constituição sobre os atos normativos internacionais, a previsão constitucional da prisão civil do depositário infiel (art. $5^{\circ}$, inciso LXVII) não foi revogada pela ratificação do Pacto Internacional dos Direitos Civis e Políticos (art. 11) e da Convenção Americana sobre Direitos Humanos - Pacto de San José da Costa Rica (art. $7^{\circ}, 7$ ), mas deixou de ter aplicabilidade diante do efeito paralisante desses tratados em relação à legislação infraconstitucional que disciplina a matéria, incluídos o art. 1.287 do Código Civil de 1916 e o DecretoLei $\mathrm{n}^{\circ} 911$, de $1^{\circ}$ de outubro de 1969 . Tendo em vista o caráter supralegal desses diplomas normativos internacionais, a legislação infraconstitucional posterior que com eles seja conflitante também tem sua eficácia paralisada. (RE 466.343).

Essa tese foi aventada, em sessão de 29 de março de 2000, no julgamento do RHC $n^{\circ}$ 79.785-RJ, pelo voto do Eminente Relator, Ministro Sepúlveda Pertence, que acenou com a possibilidade da consideração dos tratados sobre direitos humanos como documentos supralegais. O Ministro Sepúlveda Pertence manifestou seu pensamento da seguinte forma:

Desde logo, participo do entendimento unânime do Tribunal que recusa a prevalência sobre a Constituição de qualquer convenção internacional. [...] $\mathrm{Na}$ ordem interna, direitos e garantias fundamentais o são, com grande frequência, precisamente porque - alçados ao texto constitucional - se erigem em limitações positivas ou negativas ao conteúdo das leis futuras, assim como as anteriores à Constituição. [...] Se assim é, à primeira vista, parificar às leis ordinárias os tratados a que alude o art. 5o, $\S 20$, da Constituição, seria esvaziar de muito do seu sentido útil a inovação, que, malgrado os termos equívocos do seu enunciado, traduziu uma abertura significativa ao movimento de internacionalização dos direitos humanos. (RHC no 79.785-RJ).

\section{O referido entendimento consagra a hierarquia}


infraconstitucional, mas supralegal, dos tratados internacionais de direitos humanos, distinguindo-os dos demais tratados.

Em suma, existem quatro concepções diferentes acerca da hierarquia dos tratados de direitos humanos, quais sejam, a que entende pela hierarquia constitucional dos tratados de direitos humanos; a que entende pela paridade hierárquica dos referidos tratados e lei federal; a que entende pela supraconstitucionalidade desses dispositivos internacionais; e, ainda, a que entende pela hierarquia infraconstitucional, mas supralegal, dos tratados internacionais de proteção dos direitos humanos.

Segundo Piovesan, foi na intenção de responder a essa polêmica doutrinária e jurisprudencial, que a Emenda Constitucional n. 45, de 8 de dezembro de 2004 , introduziu o $\$ 3^{\circ}$, no artigo $5^{\circ}$, dispondo que:

Os tratados e convenções internacionais sobre direitos humanos que forem aprovados, em cada Casa do Congresso Nacional, em dois turnos, por três quintos dos votos dos respectivos membros, serão equivalentes às emendas à Constituição. (PIOVESAN, 2008 a, p.71).

Ante todos os argumentos expostos, o presente trabalho entende que a hierarquia constitucional dos tratados internacionais de proteção dos direitos humanos, já é conferida pelo artigo $5^{\circ}, \S 2^{\circ}$ da Constituição da República de 1988. Vale dizer, sustenta-se que, independentemente de serem aprovados, em cada Casa do Congresso Nacional, em dois turnos, por três quintos dos votos dos respectivos membros, os tratados internacionais de direitos humanos ratificados pelo Brasil têm hierarquia normativa constitucional, vez que, o parágrafo $2^{\circ}$, do mencionado dispositivo legal, já assim determina.

No entanto, Piovesan (2008 a, p.71), entende que o constituinte poderia ter sido mais claro quando redigiu o aludido parágrafo $3^{\circ}$, do artigo $5^{\circ}$. Segundo ela, seria mais adequado que a redação do parágrafo $3^{\text {o }}$ endossasse a hierarquia constitucional formal de todos os tratados internacionais de direitos humanos ratificados, "afirmando que os tratados internacionais de proteção de direitos humanos ratificados pelo Estado brasileiro têm hierarquia constitucional".

Ainda assim, o advento do parágrafo $3^{\circ}$, do artigo $5^{\circ}$ da Carta de 1988, reforça a concepção que atribui hierarquia constitucional aos tratados de direitos humanos. 


\subsection{O Valor Normativo dos Tratados Internacionais de Direitos Humanos ratificados pelo Brasil anteriormente à Emenda Constitucional n. 45}

Para então finalizar o presente estudo, importa destacar a conclusão do Ministro Celso de Mello quando proferiu seu voto no julgamento do Habeas Corpus n. 87.585, aos doze dias do mês de março de 2008:

Após muita reflexão sobre esse tema, e não obstante anteriores julgamentos desta Corte de que participei como Relator (RTJ 174/463-465 - RTJ 179/493-496), inclino-me a acolher essa orientação, que atribui natureza constitucional às convenções internacionais de direitos humanos, reconhecendo, para efeito de outorga dessa especial qualificação jurídica, tal como observa CELSO LAFER, a existência de três distintas situações concernentes a referidos tratados internacionais:

(1) tratados internacionais de direitos humanos celebrados pelo Brasil (ou aos quais o nosso País aderiu), e regularmente incorporados à ordem interna, em momento anterior ao da promulgação da Constituição de 1988 (tais convenções internacionais revestem-se de índole constitucional, porque formalmente recebidas, nessa condição, pelo $\S 2^{\circ}$ do art. $5^{\circ}$ da Constituição);

(2) tratados internacionais de direitos humanos que venham a ser celebrados pelo Brasil (ou aos quais o nosso País venha a aderir) em data posterior à da promulgação da EC $\mathrm{n}^{0}$ 45/2004 (essas convenções internacionais, para se impregnarem de natureza constitucional, deverão observar o "iter" procedimental estabelecido pelo $\S 3^{\circ}$ do art. $5^{\circ}$ da Constituição); e

(3) tratados internacionais de direitos humanos celebrados pelo Brasil (ou aos quais o nosso País aderiu) entre a promulgação da Constituição de 1988 e a superveniência da EC $\mathrm{n}^{\circ} 45 / 2004$ (referidos tratados assumem caráter materialmente constitucional, porque essa qualificada hierarquia jurídica lhes é transmitida por efeito de sua inclusão no bloco de constitucionalidade, que é "a somatória daquilo que se adiciona à Constituição escrita, 
em função dos valores e princípios nela consagrados").

Diante de todo o estudo até agora apresentado, fica fácil perceber que, a dúvida não subsiste a partir de agora. Vez que fora resolvida com o aditamento do $\S 3^{\circ}$, ao artigo $5^{\circ}$ da Constituição da República de 1988.

Assim, conclui-se que, os tratados sobre direitos humanos que o Congresso aprove, após o advento da Emenda Constitucional n.45, com o rito de aprovação da emenda à Constituição - em cada Casa do Congresso Nacional, em dois turnos, e por voto de três quintos do total de seus membros - integrarão em seguida a ordem jurídica no nível das normas da própria Constituição. Essa nova regra autoriza algumas conclusões prospectivas. Nos dizeres de Rezek:

Não é de crer que o Congresso vá doravante bifurcar a metodologia de aprovação dos tratados sobre direitos humanos. Pode haver dúvida preliminar sobre a questão de saber se determinado tratado configura realmente essa hipótese temática, mas se tal for o caso o Congresso seguramente adotará o rito previsto no terceiro parágrafo, de modo que, se aprovado, o tratado se qualifique para ter estatura constitucional desde sua promulgação - que pressupõe, como em qualquer outro caso, a ratificação brasileira e a entrada em vigor no plano internacional. Não haverá quanto a semelhante tratado a possibilidade de denúncia pela só vontade do Executivo, nem a de que o Congresso force a denúncia mediante lei ordinária (v. adiante o $\S 53$ ), e provavelmente nem mesmo a de que se volte atrás por meio de uma repetição, às avessas, do rito da emenda à carta, visto que ela mesma se declara imutável no que concerne a direitos dessa natureza (REZEK, 2007, p.101-103).

Uma última dúvida diz respeito aos tratados ratificados antes da Emenda Constitucional $n^{\circ} 45$. Quanto a essa questão, reitera-se que, por força do artigo $5^{\circ}, \S 2^{\circ}$, da Carta de 1988, todos os tratados de direitos humanos, independentemente do quorum de sua aprovação, são materialmente constitucionais, compondo o bloco de constitucionalidade. E mais, é sensato crer que, ao promulgar o parágrafo $3^{\circ}$, sem nenhuma ressalva abjuratória dos tratados sobre direitos humanos outrora concluídos mediante processo simples, o constituinte os elevou à categoria dos tratados de nível constitucional.

Igual entendimento é perfilhado por Piovesan: 


\begin{abstract}
Observe-se que os tratados de proteção dos direitos humanos ratificados anteriormente à Emenda Constitucional n. 45/2004 contaram com ampla maioria na Câmara dos Deputados e no Senado Federal, excedendo, inclusive, o quorum dos três quintos dos membros em cada Casa. Todavia, não foram aprovados por dois turnos de votação, mas em um único turno de votação em cada Casa, uma vez que o procedimento de dois turnos não era tampouco previsto. [...] O quorum qualificado está tãosomente a reforçar a natureza constitucional, ao adicionar um lastro formalmente constitucional aos tratados ratificados, propiciando a constitucionalização formal dos tratados de direitos humanos no âmbito jurídico interno. [...] Não seria razoável sustentar que os tratados de direitos humanos já ratificados fossem recepcionados como lei federal, enquanto os demais adquirissem hierarquia constitucional exclusivamente em virtude de seu quorum de aprovação. (PIOVESAN, 2008 a, p.72).
\end{abstract}

Entende-se que o novo dispositivo do art. $5^{\circ}, \S 3^{\circ}$, reconhece, de modo explícito, a natureza materialmente constitucional dos tratados de direitos humanos, reforçando, portanto, a existência de um regime jurídico misto, que distingue os tratados de direitos humanos dos tratados tradicionais de cunho comercial. Isto é, ainda que fossem aprovados pelos requisitos do parágrafo supracitado, os tratados comerciais não passariam a ter status formal de norma constitucional tão-somente pelo procedimento de sua aprovação, conforme leciona Piovesan (2008 a, p.75).

Ainda segundo entendimento de Piovesan (2008 a, p.76), importa mencionar que, o advento do $\S 3^{\circ}$ do art. $5^{\circ}$ fez surgir duas categorias diferentes de tratados internacionais de proteção de direitos humanos: os materialmente constitucionais; e, os material e formalmente constitucionais. Logo, todos os tratados internacionais de direitos humanos são materialmente constitucionais - por força do $\S 2^{\circ}$ do art. $5^{\circ}$. Para além de serem materialmente constitucionais, poderão, a partir do $\S$ $3^{\circ}$ do mesmo dispositivo, acrescer a qualidade de formalmente constitucionais, equiparando-se às emendas à Constituição, no âmbito formal.

Cabe considerar, todavia, que a diversidade de regimes jurídicos atém-se à possibilidade ou não de denunciar o tratado. Como é sabido, a denuncia é o ato unilateral pelo qual um Estado se retira de um tratado, 
assim, os tratados materialmente constitucionais podem ser suscetíveis de denúncia, enquanto que os tratados material e formalmente constitucionais não podem ser denunciados. Vez que, os direitos enunciados nestes receberam assento no Texto Constitucional pelo grau de legitimidade popular representativa. E, se assim é, não se pode permitir que um ato isolado do Poder Executivo retire tais direitos do ordenamento.

Concluído assim o raciocínio do presente estudo, acredita-se que o pensamento jurisprudencial da Suprema Corte sofreu uma grande evolução, reconhecendo o indiscutível primado que devem ostentar, sobre o direito interno brasileiro, os tratados internacionais de direitos humanos, reconhecendo ainda a necessidade de amparo e defesa a integridade dos direitos da pessoa humana.

Nesse contexto, e sob essa perspectiva hermenêutica, valorizar-seá o sistema de proteção aos direitos humanos, mediante atribuição, a tais atos de direito internacional público, de caráter hierarquicamente superior ao da legislação comum, em ordem a outorgar-lhes, sempre que se cuide de tratados internacionais de direitos humanos, supremacia e precedência em face de nosso ordenamento doméstico, de natureza meramente legal, conforme conclui também o Ministro Celso de Mello, quando do seu voto no julgamento do $\mathrm{HC}$ 87.585. Este trabalho segue o mesmo entendimento.

\section{CONCLUSÃO}

Acredita-se que, ao longo da pesquisa, foram enfrentadas as questões inicialmente propostas e que serão sintetizadas a seguir.

Os Tratados internacionais, considerados na atualidade a principal fonte do Direito Internacional, uma vez ratificados, apresentam força jurídica obrigatória e vinculante, de forma que, a violação dos mesmos, implica no descumprimento de obrigações assumidas no âmbito internacional. E, portanto, implicará na responsabilização internacional do Estado violador.

A análise dos Direitos Humanos resultou que eles são decorrência de um processo de evolução histórica da humanidade. No inicio, vão sendo conquistados. Passam então a ser reclamados e, a partir daí, caminham para positivação, que transcendem a órbita interna dos Estados, por gozarem de proteção internacional.

A incessante evolução da sociedade é responsável por ocasionar 
todas essas transformações. A contemporaneidade está vivenciando grandes mudanças na ordem mundial, as quais se dão através de fenômenos como a internacionalização dos direitos humanos.

O Direito Internacional dos Direitos Humanos é considerado um ramo moderno do Direito. Surgiu com o fim da Segunda Guerra Mundial. Ante as atrocidades cometidas pelo Nazismo, em meados do século XX, a reconstrução dos Direitos Humanos se tornou necessária. Essa preocupação girou o mundo, revelando tema de legítimo interesse internacional. Exigia-se uma ação internacional eficaz para a proteção dos Direitos Humanos. Fato este que impulsionou o processo de internacionalização desses direitos.

Daí dizer que os Direitos Humanos encontram-se no alvo da nova ordem mundial. De forma que os compromissos assumidos pelos Estados perante a comunidade internacional inauguram um novo ciclo na evolução dos direitos humanos, e, ainda, reafirmam a internacionalização destes.

Como é sabido, a forma principal de firmar compromissos entre Estados perante a comunidade internacional é, atualmente, o tratado, o qual proporciona maior efetividade na tutela e na promoção dos direitos fundamentais, interagindo com o sistema regional, bem como, com o sistema nacional de proteção, visto que todos se complementam.

Passa-se então a análise da posição do Estado brasileiro em relação ao sistema internacional de proteção dos Direitos Humanos. E conclui-se que, tanto o Direito Internacional dos Direitos Humanos, quanto a Constituição brasileira de 1988 foram concretizados com ênfase no princípio da dignidade da pessoa humana. Vale dizer, a dignidade da pessoa humana é a base dos Direitos interno e internacional.

Conseqüência disso é o encerramento da dicotomia entre as teorias monista e dualista. $\mathrm{O}$ direito interno e o direito internacional formam um todo que não se divide. Em outras palavras, ambos interagem visando a proteção máxima dos direitos da pessoa humana.

Por isso a Constituição brasileira de 1988 cuidou de abranger a promoção da inter-relação dos direitos humanos nos planos interno e internacional, incluindo os parágrafos $1^{\circ}$ e $2^{\circ}$ no artigo $5^{\circ}$ do referido diploma legal, dispondo que os tratados definidores de direitos humanos em que o Brasil seja parte integram o elenco dos direitos fundamentais constitucionalmente protegidos, direta e indiretamente, exigíveis internamente.

Logo, os Tratados Internacionais de proteção dos Direitos 
Humanos, pelo $\S 2^{\circ}$, do art. $5^{\circ}$ da Constituição Federal de 1988, ingressaram no ordenamento jurídico brasileiro com o status de norma constitucional e têm aplicação imediata a partir da ratificação.

Assim, todos os direitos inscritos nos referidos tratados de proteção dos direitos humanos, incorporando-se imediatamente no ordenamento interno brasileiro, por se tratarem de normas definidoras dos direitos e garantias fundamentais, passam a ser cláusulas pétreas do texto constitucional, não podendo ser suprimidos se quer por Emenda à Constituição.

Dessa forma, acredita-se que o novo dispositivo acrescido pela Emenda Constitucional $\mathrm{n}^{\mathrm{o}} 45$, de dezembro de 2004 (art. 50, parágrafo $3^{\circ}$ ), vem a reconhecer, de modo explícito, a natureza materialmente constitucional dos tratados de direitos humanos, reforçando a existência de um regime jurídico misto, que distingue os tratados de direitos humanos dos tratados internacionais tradicionais que dispõem de assuntos outros que não direitos humanos.

Salienta-se que, por força do artigo $5^{\circ}, \S 2^{\circ}$, da Carta de 1988, todos os tratados de direitos humanos, independentemente do quorum de sua aprovação, e se foram ratificados antes ou após a Emenda Constitucional 45, são materialmente constitucionais, compondo o bloco de constitucionalidade. E mais, é sensato crer que, ao promulgar o parágrafo $3^{\circ}$, sem nenhuma ressalva abjuratória dos tratados sobre direitos humanos outrora concluídos mediante processo simples, o constituinte os elevou à categoria dos tratados de nível constitucional.

Por último, resta dizer que a Constituição de 1988 propõe a interação do Direito Internacional e do Direito Interno, fortalecendo o sistema de proteção dos direitos humanos. Cabe ao Supremo Tribunal Federal romper em definitivo com a jurisprudência anterior acerca da legalidade ordinária dos tratados de direitos humanos e avançar para o entendimento que propõe a hierarquia normativa destes tratados, conferindo máxima efetividade à dimensão material mais preciosa da Constituição, qual seja, os direitos humanos.

\section{REFERÊNCIAS}

ACCIOLY, Hildebrando. Manual de direito internacional público. 13. ed. São Paulo: Saraiva, 1998.

\section{ARIOSI, Mariângela. Conflitos entre tratados internacionais e leis}


internas: O Judiciário Brasileiro e a Nova Ordem Internacional. 1. ed. Rio de Janeiro. São Paulo: Renovar, 2000.

BASTOS, Celso Ribeiro; MARTINS, Ives Gandra. Comentários à Constituição do Brasil. 2. ed. São Paulo: Saraiva,1989.

BITTAR, Eduardo Carlos Bianca. Metodologia da pesquisa jurídica: teoria e prática da monografia para os cursos de Direito. 2. ed. São Paulo: Saraiva, 2002.

BOBBIO, Norberto. A era dos direitos. Tradução de Carlos Nelson Coutinho. Rio de Janeiro: Campus, 1992.

. O positivismo jurídico: lições de filosofia do direito. Tradução de Márcio Pugliesi et al. São Paulo: Ícone, 1995.

BOSON, Gerson de Brito Mello. Direito internacional público: o estado em direito das gentes. 3. ed. Belo Horizonte: Del Rey, 2000.

BRASIL, Constituicao (1988). Constituicao da República Federativa do Brasil. 2008.

BRASILIA. Informativo do Supremo Tribunal Federal n 495 de 18 a 22 de fevereiro de 2008. Disponível em:

$<$ http://www.stf.jus.br//arquivo/informativo/documento/informativo495.h tm\#Prisão\%20Civil\%20de\%20Depositário\%20Judicial\%20Infiel>.

BRASILIA. Informativo do Supremo Tribunal Federal n 498 de 10 a 14 de março de 2008. Disponível em:

$<$ http://www.stf.jus.br//arquivo/informativo/documento/informativo498.h tm\#Alienação\%20Fiduciária\%20e\%20Depositário\%20Infiel\%20$\% 204>$.

CANOTILHO, J. J. Gomes. Direito constitucional. 6. ed. Coimbra: Almedina, 1993.

COMPARATO, Fábio Konder. A afirmação histórica dos direitos humanos. 5. ed. São Paulo: Saraiva, 2007. 
GOMES, Luiz Flávio. Artigo: Conflito entre a Constituição brasileira e os tratados de direitos humanos. 2008. Disponível em:

$<$ http://jus2.uol.com.br/doutrina/texto.asp?id=11100>.

JAYME, Fernando G. Direitos Humanos e sua efetivação pela corte interamericana de direitos humanos. Belo Horizonte: Del Rey, 2005.

LOPES, Anselmo Henrique Cordeiro. Artigo: A força normativa dos tratados internacionais de direitos humanos e a Emenda

Constitucional n. 45/2004. 2005. Disponível em:

$<$ http://jus2.uol.com.br/doutrina/texto.asp?id=6157>.

MAZZUOLI, Valério de Oliveira. Artigo: Os tratados internacionais de proteção dos direitos humanos e sua incorporação no ordenamento brasileiro. 2000 a. Disponível em:

$<$ http://www.planalto.gov.br/ccivil_03/revista/rev_21/artigos/art_valerio. htm>.

. O poder legislativo e os tratados internacionais. 2001.

Disponível em: <http://bdjur.stj.gov.br/jspui/handle/2011/19784>.

. Hierarquia constitucional e incorporação automática dos tratados internacionais de proteção dos direitos humanos no ordenamentobrasileiro. 2000b. Disponível em:

$<$ http://www.senado.gov.br/web/cegraf/ril/Pdf/pdf_148/r14815.pdf>.

A tese da supralegalidade dos tratados de direitos humanos.

2009. Disponível em: <http://jus2.uol.com.br/doutrina/texto.asp? $\mathrm{id}=12584>$.

MELLO, Celso D. de Albuquerque. Curso de direito internacional público. 13. ed. Rio de Janeiro. São Paulo: Renovar, 2001.

MENDES, Gilmar Ferreira; COLEHO, Inocêncio Mártires; BRANCO, Paulo Gustavo Gonet. Curso de direito constitucional. 2. ed. São Paulo: Saraiva, 2008.

MENEZES, CELSO ANTÔNIO MARTINS. Artigo: A importância dos tratados e o ordenamento jurídico brasileiro. 2004. Disponível em: 
$<w w w . s e n a d o . g o v . b r / s f /$ senado/unilegis/pdf/>.

MORAES, Alexandre de. Direito constitucional. 19. ed. São Paulo: Atlas, 2006.

PEREIRA, André Goncalves; QUADROS, Fausto de. Manual de direito internacional público. 3. ed. Coimbra: Almedina, 1993.

PIOVESAN, Flávia. Direitos humanos e o direito constitucional internacional. 9. ed. São Paulo: Saraiva, 2008a.

. Tratados internacionais de proteção dos direitos humanos:

jurisprudência do STF. 2008b. Disponível em:

$<$ http://www.defensoria.sp.gov.br/dpesp/Repositorio/31/

Documentos/Artigos/00000034-001_FlaviaPioveasn.pdf>.

RAMOS, André de Carvalho. Teoria geral dos direito humanos na ordem internacional. Rio de Janeiro: Renovar, 2005.

REALE, Miguel. Lições preliminares de direito. 24 ed. São Paulo: Saraiva, 1999.

REZEK, José Francisco. Direito internacional público: curso elementar. São Paulo: Saraiva, 2000.

. Direito internacional público: curso elementar. 10. ed. São

Paulo: Saraiva, 2007.

RIBEIRO, Patrícia Henriques. As relações entre o direito internacional e o direito interno: conflito entre o ordenamento brasileiro e normas do Mercosul. Belo Horizonte: Del Rey.

RIO DE JANEIRO. Supremo Tribunal Federal. Habeas Corpus n.

72.131-1 de 23 de novembro de 1995. Impetração suscitando nulidade de prisão civil de depositário infiel. Disponível em:

$<$ http://www.stf.jus.br/portal/inteiroTeor/pesquisarInteiroTeor>.

RIO DE JANEIRO. Supremo Tribunal Federal. Recurso Extraordinário n. 79.785 de 29 de março de 2000. Recurso suscitando o duplo grau de 
jurisdição do direito brasileiro à luz da Constituição e da Convenção Americana de Direitos Humanos. Disponível em:

$<$ http://www.stf.jus.br/portal/inteiroTeor/pesquisarInteiroTeor $>$.

SÃO PAULO. Supremo Tribunal Federal. Recurso Extraordinário n. 466.343 de 28 de julho de 2006. Impetração suscitando inconstitucionalidade da prisão civil do devedor fiduciante em contrato de alienação fiduciária em garantia. Disponível em:

$<$ http://www.stf.jus.br/portal/inteiroTeor/pesquisarInteiroTeor>.

SENTENÇA. Corte Internacional de Justiça - Casos da Plataforma Continental do Mar do Norte. 1969. Disponível em:

$<$ http://www.cedin.com.br/060topic_pdf/pdf_cij/casos $\% 20$ conteciosos_1967.pdf $>$.

SERGIPE. Supremo Tribunal Federal. Recurso Extraordinário n. 80.004 de 01 de junho de 1977. Recurso suscitando a validade da Convenção de Genebra - Lei uniforme sobre letras de câmbio e notas promissórias aval aposto a nota promissória não registrada no prazo legal, impossibilidade de ser o avalista acionado. Disponível em: $<$ http://www.stf.jus.br/portal/inteiroTeor/pesquisarInteiroTeor $>$.

TOCANTINS. Supremo Tribunal Federal. Habeas Corpus n. 87.585 de 12 de março de 2008. Impetração suscitando nulidade de prisão civil de depositário infiel. Disponível em:

$<$ http://www.stf.jus.br/portal/inteiroTeor/pesquisarInteiroTeor $>$. 
